NBER WORKING PAPER SERIES

\title{
FINANCIAL GLOBALIZATION, CORPORATE GOVERNANCE, AND EASTERN EUROPE
}

\author{
René M. Stulz \\ Working Paper 11912 \\ http://www.nber.org/papers/w11912 \\ NATIONAL BUREAU OF ECONOMIC RESEARCH \\ 1050 Massachusetts Avenue \\ Cambridge, MA 02138 \\ January 2006
}

Reese Chair in Banking and Monetary Economics at the Ohio State University and Research Associate at the NBER. Prepared for the Conference on European Economic Integration, Vienna, November 2005. I am grateful to Carrie Pan for research assistance and for conference participants for comments. The views expressed herein are those of the author(s) and do not necessarily reflect the views of the National Bureau of Economic Research.

(C2006 by René M. Stulz. All rights reserved. Short sections of text, not to exceed two paragraphs, may be quoted without explicit permission provided that full credit, including $\odot$ notice, is given to the source. 
Financial Globalization, Corporate Governance, and Eastern Europe

René M. Stulz

NBER Working Paper No. 11912

January 2006

JEL No. G11, G15, G32, F30

\begin{abstract}
$\underline{\text { ABSTRACT }}$
For many countries, the most significant barriers to trade in financial assets have been knocked down. Yet, the financial world is not flat because poor governance prevents firms from being widely held and from taking full advantage of financial globalization. Poor governance has implications for corporate finance as well as for macroeconomics. I show that poor governance in Eastern Europe is accompanied, as expected, by high corporate ownership concentration, low firm valuation, poor financial development, and low foreign participation.

René M. Stulz

Fisher College of Business, Ohio State University

806A Fisher Hall

2100 Neil Avenue

Columbus, OH 43210-1144

and NBER

stulz@cob.osu.edu
\end{abstract}


In his recent book, Friedman (2005) makes the case that globalization leads to a flat world. ${ }^{1}$ By that, he means that it removes obstacles that, in the past, would have prevented firms and individuals from competing with each other across the world. Such competition improves welfare not only by insuring that goods are produced at the lowest cost but also by making sure that consumers get access to new and better goods. Assuredly, the world is not flat yet. Nevertheless, the metaphor is helpful to understand the forces that shape our world. It is even more apt to describe the financial world than the world of trade in goods.

For many countries, the most significant explicit barriers to trade in financial assets have been knocked down. Economists believe that this liberalization is extremely beneficial, because it enables investors worldwide to share risks better. Capital can be allocated more efficiently, and countries can exploit their comparative advantage better. With complete financial globalization and perfect markets within countries, welfare is maximized. Further, asset prices, portfolios, and firm financial policies are not country-dependent.

Despite a dramatic increase in cross-border trade in financial assets, the positive impact of financial globalization has been surprisingly limited. Capital does not flow to countries with low capital stocks as strongly as one would expect if the financial world were flat. ${ }^{2}$ As Lucas (1990) points out forcefully, differences in the marginal product of capital between industrialized countries and emerging countries are large. In fact, over the recent past, capital has come rushing into the U.S., when one would expect it instead to flow to emerging countries. According to data from the IMF, the cumulative sum of net equity flows to less developed countries from 1996 to 2004 is a negative $\$ 67.4$ billion. ${ }^{3}$

What are the obstacles left that make the financial world full of ridges and mountains, so that capital does not flow where the physical marginal product of capital is highest? The answer is that what I call the twin agency problems (see Stulz (2005)), poor corporate governance and high political risk, stand in the way of countries getting the full benefit of financial globalization. When the twin agency problems are serious, diffuse ownership is not feasible. Consequently, risk cannot be spread efficiently across investors 
throughout the world because the corporate insiders must bear much of a firm's risk. Ownership concentration limits a country's ability to benefit from financial globalization. It leads to lower financial development, more consumption volatility, stronger correlation between savings and investment, less foreign investment, lower firm valuations, smaller firms, and lower economic growth.

In this paper, I first analyze the implications of the twin agency problems for how firms are owned and governed. I then discuss how these twin agency problems restrict firms and countries from taking full advantage of financial globalization. I finally turn to Eastern Europe and provide evidence that the twin agency problems affect these countries adversely and prevent them from capturing the full benefit of financial globalization.

\section{The twin agency problems.}

Consider a country with a high physical productivity of capital. For a marginal dollar of capital that could be invested anywhere in the world to be invested in that country, it has to be that the investors expect to receive a return on that dollar which is, after taking into account risk, at least as high as they could get anywhere else in the world. Poor governance can make it impossible for that marginal dollar to be invested in the country because poor governance decreases the cash flows investors can expect to receive from capital raised by the firm and hence the value of their claims on the firm. When the governance problems are sufficiently serious, the firm cannot promise a high enough dollar return to investors to raise capital to exploit its investment opportunities.

The reason a firm with poor governance cannot promise a sufficient dollar return to investors is that each firm has to resolve a fundamental agency problem which arises because corporate insiders maximize their own welfare rather than the welfare of outside investors. There are many ways for insiders to take advantage of outside investors. In countries where the rule of law is strong, the concern is often that managers choose to build empires rather than maximize shareholder wealth. In such countries, the socalled free cash flow problem is therefore an important component of agency costs. However, in countries 
where the rule of law is weaker, insiders can expropriate outside investors more directly. For instance, related transactions can be used to transfer wealth from firms with outside investors to insiders. For instance, as discussed in Desai, Dyck, and Zingales (2005), a favorite approach by Russian oil companies has been to sell oil at prices substantially below the world prices to privately held companies, so that outside shareholders in the oil companies received only a fraction of the cash flows generated by oil produced by these companies. When the mechanisms that prevent corporate insiders from taking advantage of outside investors are weak, a higher fraction of the return from a marginal dollar of investment is expected to be siphoned off by corporate insiders, hence the physical productivity of a marginal dollar of investment has to be large to offset the amount expected to be siphoned off and still make it worthwhile for outside investors to invest.

Besides the agency problem that arises between corporate insiders and investors, there is another agency problem, which is at the state level. When the state works poorly, those who control the state pursue their objectives rather than enforcing property rights and facilitating contracting among private parties. They can either expropriate investors directly or impose additional costs on investors, but either way they reduce the payoff to investors from investing in the country. The agency problems within the firm and within the state form what I call the twin agency problems.

Pinkowitz, Stulz, and Williamson (2005) provide a useful way to understand the importance of the governance problem as an obstacle to financial globalization. One would expect a dollar of cash to be worth a dollar when a corporation is valued by the capital markets when governance works well. If a dollar of cash were worth less than a dollar, it would mean that part of the cash is wasted by managers or controlling shareholders. We investigate how capital markets assess the value of cash in 35 countries from 1988 through 1998. Their sample includes more than 6,000 companies per year on average. They show that the value of a dollar of cash is worth $\$ 0.91$ in countries with low corruption and only $\$ 0.33$ in countries with high corruption. While the value of a dollar of cash inside the corporation is worth an amount not significantly different from $\$ 1$ in countries with low corruption, it is worth significantly less 
in countries with high corruption. Furthermore, they find that dividends are worth a lot more in countries with high corruption than they are in countries with low corruption. In other words, investors value cash paid out by the corporation in countries with high corruption more because they have good reasons to expect that cash kept within the firm will be wasted or stolen.

\section{a. The firm agency problem and corporate ownership.}

To illustrate the implications of the twin agency problems for firm ownership and risk-bearing, let's consider an economy in which there are two types of investors, entrepreneurs and portfolio investors. While some agents can only be portfolio investors, the others, namely, the entrepreneurs, have each a unique investment opportunity. If an entrepreneur takes advantage of her unique investment opportunity, she starts a firm, sells equity to outside investors, and becomes a corporate insider. If she decides to pass on the investment opportunity, she becomes a portfolio investor. At the end of a period of time, the investment opportunity pays a random cash flow. To simplify the analysis, let us assume that the firm liquidates after the random cash flow is realized.

In a world of perfect markets where the twin agency problems do not exist, the cash flow would be paid out to the investors in proportion to their agreed upon rights. With the twin agency problems, both corporate insiders and the rulers of the sovereign state have the ability to expropriate some of the firm's cash flow. Because the corporate insiders manage the firm, they have the opportunity to expropriate cash flow first. The rulers of the sovereign state can expropriate some of the cash flow next. The cash flow left after expropriation by corporate insiders and by the state rulers is distributed as a liquidating dividend.

If an entrepreneur chooses to become a portfolio investor, her wealth at the end of the period is given by the value of her portfolio. In contrast, if she takes advantage of her investment opportunity, her wealth at the end of the period is the sum of the cash flow that she expropriates from the firm plus the liquidating dividends she receives. It is common to call the cash flow expropriated a private benefit from control. The private benefits from control can also, however, take other forms than cash. For instance, insiders may 
enjoy some types of investments more than others and may therefore use the resources of the firm to make the investments they enjoy even if doing so hurts outside investors.

If the state let corporate insiders consume private benefits freely, firms would not exist unless corporate insiders could find ways to commit not to consume private benefits. So, in general, there are two sources of costs when corporate insiders consume private benefits. First, laws and regulations may punish the insiders who consume private benefits. This is the investor protection provided by the state. The extent to which it is successful in preventing excessive consumption of private benefits depends on the nature of the laws, on the quality of the judicial system, and on how well the laws are enforced. Second, corporate insiders can find ways to commit to low consumption of private benefits. This is the investor protection provided by the firm.

To understand the implications of poor investor protection, it is useful to think of the case in which corporate insiders can consume private benefits, but they pay a deadweight cost when they expropriate investors because they expend effort to do so and because they might get caught and punished. This cost varies across countries and increases with the amount of expropriation. The cost is higher in countries with better investor protection.

When insiders sell shares to the public, the capital markets reduce the share price by the present value per share of the expected consumption of private benefits. Once the shares are sold, it would make no sense for insiders not to consume the private benefits they are expected to consume since they already paid for them by selling shares at a low price. However, because of the deadweight costs, a dollar of private benefits costs more than a dollar for insiders, so that they would prefer to find a way to commit to lower consumption of private benefits. Let's assume first that corporate insiders can commit to lower consumption of private benefits through their ownership share in the firm.

As corporate insiders consume more private benefits, the liquidating dividend paid to shareholders falls since private benefits reduce the resources available for distribution to shareholders. Consequently, corporate insiders receive a smaller liquidating dividend for the shares they own when they consume 
more private benefits. Since their share of the liquidating dividend is given by their ownership share of the firm's equity, the insiders incur a higher cost from consuming private benefits when they own a larger fraction of the firm's equity. Therefore, the insiders' net gain from private benefits before deadweight costs falls as their firm ownership increases. However, since the deadweight costs depend on the consumption of private benefits, they do not fall as firm ownership increases for a given amount of consumption of private benefits. Consequently, as ownership increases, the gain from consuming private benefits falls, but the cost from doing so does not, making consumption of private benefits less advantageous. The decision rule of insiders is to consume private benefits up to the point where the marginal net gain from these benefits before deadweight costs equals the increase in deadweight cost from consuming additional private benefits. Since the deadweight costs increase with the consumption of private benefits, insiders consume fewer private benefits when their ownership of the firm is higher because they pay more for these private benefits themselves.

In the model described above, the only way for the insiders to commit to consuming fewer private benefits is to increase their ownership of the firm's cash flow. However, insiders can own a larger stake only if they have the means to do so. As a result, if investor protection is poor, firm creation depends more on the wealth of insiders than otherwise. Further, if insiders have a larger stake in their own firm, they have to bear more firm-specific risk than if they could invest all their wealth in a well-diversified portfolio.

Firms can take steps to improve governance. For instance, they can choose to hire high quality auditors or to have independent directors. Such steps enable corporate insiders to reduce their ownership stake in the firm's cash flows and hence make it possible to raise more capital externally. However, a firm's costs and benefits from taking steps to improve governance depend heavily on the country in which it is located for three reasons:

1) It is much cheaper for a firm to commit to good governance if it can write contracts that are cheap to enforce. Consequently, firm-level investor protection is cheaper when a country has 
good laws and a judicial system that works well. For instance, firms can choose charter provisions that make it more difficult for insiders to expropriate investors. However, these provisions are only valuable to the extent that the courts can be used to enforce them.

2) Mechanisms of good governance require the availability of resources that are often scarce in countries with low economic development. For instance, it is harder for insiders to expropriate outside investors if the auditors are competent and not corrupt. Such auditors are harder to find in countries with poor economic development. Similarly, an independent and knowledgeable press is extremely valuable in monitoring corporate insiders as pointed out by Dyck and Zingales (2004), but there is no such press in many countries.

3) Good governance is valuable when a firm wants to raise capital since it lowers the cost of capital. However, if a firm is located in a country with poor financial development, the ability of firms to raise capital locally is limited, so that the incentives for good governance are low to start with.

The heavy dependence of the costs and benefits of good governance on country characteristics explains the findings of Doidge, Karolyi, and Stulz (2005a). In that paper, they investigate the extent to which firm characteristics and country characteristics can explain the quality of firm governance. They use three corporate governance rankings: the S\&P Transparency and Disclosure ratings, the governance ratings of Credit Lyonnais Securities Asia (CSLA), and the FT-ISS governance ratings. Their key finding is that most of the variation in corporate governance rankings can be explained by country characteristics. In particular, regressions of the S\&P, CSLA, and FT-ISS ratings on country dummy variables have adjusted R-squares of, respectively, 39 percent, 73 percent, and 72 percent. In contrast, regressions of these ratings on firm characteristics have R-squares of less than 10 percent for the CSLA and FT-ISS ratings and of 22 percent for the $S \& P$ ratings. 


\section{b. The state agency problem and the corporation.}

Like corporate insiders, state rulers pursue their own objectives. The institutions of the state limit the ability of state rulers to maximize their welfare at the expense of their constituents. For instance, in a democracy, state rulers who pursue their own objectives at the expense of the electorate do not get reelected. However, state rulers who have a lot of power but do not expect to enjoy this power for a long time can find it advantageous to use the powers of the state for their own benefit. ${ }^{4}$ Further, even when no one person monopolizes state power, coalitions can develop that find it optimal to expropriate those who do not belong to the coalition. This expropriation can take many forms. I focus on the type of expropriation that reduces the returns to outside investors.

A significant threat of expropriation by state rulers also leads to coinvestment by corporate insiders. State rulers can impose redistributive taxes, confiscate assets, forbid some activities, or require bribes to enrich themselves. Even though Yukos comes to mind, it should be clear that the term "expropriation" covers a wide range of activities, many of which are common in developed countries. For instance, Roe (2003) shows that state and union interference in corporations is frequent in European countries and affects how corporations are owned and organized.

Corporate insiders can reduce the state's proceeds from expropriation by increasing their bargaining power with the state. They can do this by making themselves more critical to the success of the firm through their choice of investment policies, its contracting policies, and its financing policies.

When management becomes more indispensable to a firm, it also decreases its cost of consuming private benefits as it becomes less subject to discipline from the market for corporate control, the labor market, and shareholders. (Shleifer and Vishny (1989) analyze this in their paper on managerial entrenchment.) Consequently, the gains that shareholders make as corporate insiders are better able to reduce the expropriation by the state may be offset by losses due to increased consumption of private benefits on the part of insiders. 
Further, when management has a small stake in the firm's cash flows, it may use its entrenched position to extract the best deal from the state for itself, rather than use its power to protect shareholders. This makes the separation of ownership and control inefficient when state expropriation is significant. By having control, the corporate insiders can make decisions that limit the potential for state expropriation. By having a large stake in the firm's cash flows, they provide assurance to outside investors that they will make decisions that benefit all investors. Absent such a stake, they could let the state expropriate minority shareholders at will, in exchange for the right granted by the state to appropriate more private benefits.

Though, so far, the twin agency problems have been analyzed separately, it is important to note that they can feed on each other. First, corporate insiders can be connected with state rulers, and if they are, they can use the state to steal from other investors. Rajan and Zingales (2003) show how business incumbents can use laws and regulations to tilt the playing field in their favor, thus hindering financial development that would benefit new firms. Second, state rulers can help corporate insiders protect their private benefits. Recent papers by Fisman (2001), Johnson and Mitton (2003), and Faccio (2005) illustrate the benefits corporate insiders can derive from connections with the state. Capture of these benefits generally requires opaqueness. Third, the consumption of private benefits is implicitly subsidized by the state in countries where the threat of state expropriation is economically significant. This is because the consumption of private benefits tends to be hidden from the state, so such benefits are less likely to be expropriated by the state than are firms' cash flows remaining after insiders have extracted their private benefits. Fourth, corporate insiders can use corporate resources to bribe state rulers so that they can keep and extend their private benefits. As a result, corporate insiders have little incentives to lobby for a transparent state and to fight against corruption. The state agency problem can therefore feed on the firm--level agency problem. 


\section{The twin agency problems, corporate finance, and the benefits from financial globalization.}

The twin agency problems have far reaching implications for corporate finance, for financial development, and for how countries benefit from financial globalization. I discuss these implications in this section, starting with concentrated ownership.

\section{a. The implications of ownership concentration for corporations.}

So far, I have shown theoretically that corporate insiders have to co-invest more with outside investors, and ownership becomes more concentrated as the twin agency problems become more important. The twin agency problems explain the compelling empirical evidence that corporate ownership is highly concentrated in countries where investor rights are poorly protected. La Porta, Lopez-de-Silanes, and Shleifer (1999) investigate the corporate ownership of the 20 largest firms as well as of some smaller firms in 27 countries. They find that, except in countries with good investor protection, few firms are widely held. Typically, most firms have a family as a controlling shareholder. In countries that protect shareholder rights well, they find that $\mathbf{4 7 . 9 2}$ percent of firms are widely held, in that no shareholder holds more than 20 percent of the votes. Using that criterion (p. 494), these authors find that in countries with poor shareholder rights, only 12.67 percent of the firms are widely held. Stulz (2005) uses a measure of ownership available for more firms and countries, but somewhat less precise, namely the sum of insider and block ownership reported by Worldscope. The paper uses a proxy for each one of the twin agency problems and finds that insider ownership increases as the protection of minority shareholders becomes weaker and as political risk increases.

The twin agency problems have an adverse impact on entrepreneurship. This is because, everything else equal, the rewards from starting a firm in a country where the twin agency problems are important are much less than what they would be in a country where these problems are less important. In countries where the twin agency problems are important, there are deadweight costs from entrepreneurship that do not exist in other countries. The terms on which entrepreneurs can raise equity are inversely related to the 
importance of the twin agency problems. When these problems are serious, outside investors expect less of a dollar return on the firm's equity. Consequently, many firms that could get financed in countries where the twin agency problems are smaller cannot be financed in countries where they are more serious.

If it is optimal for ownership to be highly concentrated, it follows that the size of a firm is largely determined by the resources of the insiders and by their willingness to bear the firm's risk. Since the resources of insiders and their willingness to bear risk are limited, the total amount of equity of the firm is therefore limited by the insiders' capacity to acquire this equity. If the firm is successful and has to raise funds to expand, it can only do so if the capacity of insiders to subscribe to an equity issue is not exhausted. To avoid diluting ownership of cash flows, insiders can raise funds through debt. However, as a result, the firm will be more highly levered and hence more fragile. It follows that countries where the twin agency problems are more serious tend to have smaller firms and more highly levered firms.

Concentrated ownership has implications for the firm's risk management decisions. With concentrated ownership, the corporate insiders have to bear much of the risk of new projects. Since insiders are risk averse, they may therefore turn down projects because of the increased level of risk they have to bear. If, instead, ownership were dispersed, the firm could take on these projects since the risk would be shared among many investors. As John, Litov and Yeung (2005) show, insiders in countries with high private benefits also find it valuable to take on less risk to the extent that the claim to private benefits is more similar to a debt claim. In Myers and Jin (2005), insiders can even find it optimal to bail out the firm in bad states of the world so that they keep control of the firm. For all these reasons, one would expect firms in countries with poor investor protection to take less risky projects unless they can find ways to hedge their risks. However, countries with poor protection are often countries where the availability of hedging instruments is limited. Consequently, in such countries, firms are more likely to manage risks by diversification and through investment policy. Both of these approaches to risk management are expensive. 
Consider now the impact of financial globalization on firms. In a flat financial world, the cost of capital required by outside investors would be the same everywhere in the world. Consequently, firms in any country could raise funds to finance projects that would be profitable elsewhere. With the twin agency problems, the financial world is not flat. Investors expect the same return for a given amount of risk on investments everywhere in the world. However, the expected return required by investors does not measure the cost of equity for corporate insiders. To raise equity, corporate insiders have to co-invest with outside investors in countries where the twin agency problems are significant. This coinvestment is costly for corporate insiders because it forces them to bear more firm-specific risk. The twin agency costs introduce a wedge between the cost of equity required by the capital markets and the cost of equity for insiders. The extent to which a country benefits from financial globalization is inversely related to the size of this wedge.

Figure 1 makes this point graphically. The downward-sloping curve shows the marginal product of capital for the firm. In a world without financial globalization, the cost of capital would be fixed (as long as the firm is small enough) at the autarchy cost of capital. Empirical evidence on financial globalization shows that it reduces the cost of capital. ${ }^{5}$ The reduction in the cost of capital associated with financial globalization leads to an increase in the amount of capital invested in a firm since new investment opportunities become profitable at the lower cost of capital.

Figure 2 takes into account the twin agency problems. With these problems, the cost of capital for corporate insiders is no longer the required expected return on capital required by outsiders. The twin agency problems introduce deadweight costs for corporate insiders that make capital more expensive. In particular, when raising external capital, corporate insiders have to bear the deadweight costs associated with the consumption of private benefits. In addition, since they have to co-invest, they have to bear more risk which is also costly for them. The capacity of insiders to absorb more equity is limited. Consequently, if they were close to capacity before financial globalization, they cannot absorb much more equity afterwards. It follows that in this extreme case the impact of financial globalization is extremely 
limited. In Figure 2, the cost to insiders of increased capital raised therefore increases sharply as more capital is raised. Of course, in the case where the capacity of corporate insiders to absorb equity is large, the deadweight costs become less significant and financial globalization has much more of an impact.

So far, I have assumed that it is worthwhile for corporate insiders to start the firm. Financial globalization increases the opportunity cost of starting firms, since the expected utility of portfolio investors increases as a result of international diversification. It is therefore possible that financial globalization can lead to fewer firms being created when the twin agency problems are very serious. Further, corporate insiders may also choose not to reinvest cash flows in existing firms, because they wish to reduce their investment in their firms when portfolio investment becomes more attractive.

Unfortunately, countries with bad governance face a vicious circle. When a country protects investors poorly, financial markets are poorly developed. When financial markets are poorly developed, there are few incentives for firms to protect investors better or for politicians to reform governance. Financial globalization can help to break that vicious circle by enabling firms to access the deep capital markets of countries that protect investors well and to enable local firms to rent the institutions of these countries. With financial globalization, firms can rent institutions from countries with better institutions (see Stulz, 1999b). In particular, foreign firms that list their shares in the U.S. benefit from some U.S. institutions. For instance, they have to meet various disclosure requirements that U.S. firms have to meet and their investors can rely on the U.S. courts and benefit from the U.S. laws and regulations.

Doidge, Karolyi and Stulz (2004) examine whether the evidence is consistent with the hypothesis that firms cross-list in the U.S. to take advantage of the U.S. institutions that protect investors. They find strong support for this hypothesis. They also report a large "listing premium," i.e, foreign firms that list in the U.S. are worth substantially more than foreign firms that do not. The authors examine the valuation of 712 cross-listed stocks and 4,078 non-cross-listed stocks in 1997 and estimate that cross-listed firms were worth 16.5 percent more on average than comparable firms that were not cross-listed. This cross-listing premium was even more dramatic for firms listed on NYSE, where it was 37 percent on average. In recent 
work, not yet circulating as a working paper, we show that this cross-listing premium persists through time.

\section{b. The macroeconomic implications of concentrated ownership.}

Concentrated ownership has implications for asset holdings, for the savings and investment relation, for the distribution of consumption, and for economic growth. Mean-variance portfolio investors hold their country's market portfolio when their country is completely segmented from world capital markets, and they hold the world market portfolio when their country becomes completely integrated in world markets. When concentrated ownership is optimal, insiders cannot hold a well-diversified portfolio, because they overweight their firms' shares in their portfolios. ${ }^{6}$ It necessarily follows that outside investors must underweight the firm in their portfolios. For instance, if insiders typically hold 50 percent of cash flow rights in a country, this means that portfolio investors can only hold 50 percent of a country's market portfolio. Consequently, in countries where the twin agency problems are significant, aggregate equity holdings will show a home bias as long as corporate insiders are local residents and cannot hedge their holdings, which is typically the case. The home bias induced by concentrated ownership is made worse, as shown by Giannetti and Simonov (2005), by the fact that foreign investors have less of a comparative advantage than some domestic investors in monitoring and assessing consumption of private benefits. In a recent paper, Bae, Stulz, and Tan (2005) show that local investors have more of an information advantage in more opaque economies.

Such a home bias has important implications for the distribution of aggregate wealth, saving, investment, and consumption for a country. If investors hold the world market portfolio, their wealth will be perfectly correlated with the return of that portfolio. Consequently, the wealth of investors across the world will be perfectly correlated. However, with a home bias, the wealth of investors in a country will be more correlated with the market portfolio of that country than with the world market portfolio. As wealth becomes imperfectly correlated across countries, savings and consumption are imperfectly correlated 
also. In particular, with the home bias, a positive shock to the local economy mostly increases domestic wealth and local savings. Presumably, the shock makes investment in the local economy attractive as well, so that shocks to the local economy induce a correlation between savings and investment. It follows that concentrated ownership can help explain the so-called Feldstein-Horioka paradox. ${ }^{7}$

There is a more direct link between savings and investment that results from concentrated ownership. If the local economy experiences a positive shock, so that it has better than expected investment opportunities, firms can invest in response to these improved investment opportunities only to the extent that corporate insiders can coinvest with outside investors. It follows that if corporate insiders are constrained in their ability to coinvest, domestic growth will be limited. From this perspective, local savings constrain investment in that an increase in domestic wealth makes it easier for corporate insiders to co-invest with outside investors and hence for investment to be financed.

With concentrated corporate ownership, insiders cannot diversify their portfolio as much as they would if dispersed ownership were optimal. Consequently, concentrated ownership induces a positive correlation between the corporate insiders' consumption and their firms' cash flow. In the absence of concentrated ownership, all investors' wealth would behave as if they were portfolio investors because they would have well-diversified portfolios. If we could ignore labor income or assume it can be hedged, investors' consumption would be perfectly correlated across the world. With concentrated ownership, consumption is more correlated with the country's GNP, so that domestic shocks have more of an impact on consumption.

Consider a closed economy where firms have available projects that have high risk and high expected payoffs. In a closed economy, firms will reject some these projects because the cost of capital for these projects is too high as a result of the fact that their risk has to be born within the economy. As soon as the economy liberalizes, the cost of capital for these projects falls because their risk can be spread across the world. In a world of dispersed ownership, firms would take on these projects after liberalization. ${ }^{8}$ Obstfeld (1994) shows that, because of this mechanism, financial liberalization leads to an increase in 
economic growth. With concentrated ownership, the corporate insiders may choose to reject these projects because they would have to bear more risk if they took them on. Though the cost of capital for these projects falls with financial globalization, risk-averse corporate insiders cannot diversify the risk of these projects because they have to coinvest with outside investors. It follows that growth will be lower on average in countries with concentrated ownership because firms will turn down good projects that firms in countries with dispersed ownership would take advantage of.

\section{Ownership concentration and governance in Eastern Europe.}

In this section, I provide some evidence showing that the problem of poor governance significantly limits the benefits from financial globalization for Eastern European countries.

In Section 2, I argued that poor governance leads to high ownership concentration. To investigate the quality of governance, I use data from the World Bank. This data represents averages of rankings across a number of governance indicators. For each category, the data gives a percentile for a country. Table I shows that the overall governance rating, Eastern Europe increased from the $55^{\text {th }}$ percentile in 1996 to the $60^{\text {th }}$ percentile in 2004 . The table compares the overall ranking to the ranking for countries in the same income category. It can be seen there that the Eastern European countries rank somewhat better than they would compared to countries with similar income. At the same time, however, the ranking of the Eastern European countries is much lower than the average of the Western countries. The table also provides two additional rankings. The first one is for the rule of law and the second for corruption. For both of these rankings, Eastern European countries rank slightly better than countries with comparable income, but dramatically lower than the Western countries. The bottom line is that there is room for much progress in governance.

Figure 3 reports the distribution of insider ownership for Eastern European countries for which data is reported on Worldscope for blockholders. For each country, I use data reported on Worldscope to compute the average percentage of market capitalization held by corporate insiders across firms. These 
data have important limitations, since the reporting requirements and accuracy of firm disclosures vary widely across countries. Further, insider ownership consists of the sum of blocks of shares owned, which may include blocks unrelated to the controlling shareholders.

Worldscope has ownership data for four Eastern European countries for 2002. It covers 25 firms from the Czech Republic, 33 from Hungary, 63 from Poland, and 315 from Turkey. Ownership is most concentrated in the Czech Republic, where the equally-weighted average of block ownership is 83.6 percent. For each of these four countries, insider ownership is higher than for the typical Western European country. For instance, the value-weighted average block ownership has a median of 37.74 percent among Western European countries. The lowest value-weighted block ownership is in Hungary where it is 44.4 percent. For the other Eastern European countries, block ownership is at least 50 percent higher than it is in the median Western European country and is more than four times what it is in the US. Figure 4 shows the equally-weighted average of block ownership for each country in Eastern Europe starting from when data became available. The figure shows that block ownership has not decreased over time.

Other data sources indicate very high ownership concentration in Eastern European countries also. Klapper, Laeven, and Love (2005) report that the largest shareholder in a sample of 74 Czech firms holds 69 percent of shares and the five largest shareholders hold 89 percent. The equivalent numbers for Hungary are 52 percent and 96 percent and for Poland are 39 percent and 64 percent. Pajuste (2002) estimates that the largest shareholder controls 61.1 percent of the votes on average in the Czech Republic in 2001, 44.7 percent in Hungary in 2000, and 44.6 percent in Poland in 2000. The study also provides information on ownership of voting rights in other Eastern Europe countries and finds similar numbers. Our estimates are mostly in between the Pajuste (2002) and the Klapper, Leuven, and Lowe (2005) estimates. The differences show that assessing ownership concentration is not straightforward in less than transparent countries. However, all studies show a high ownership concentration in Eastern European countries compared to Anglo-Saxon countries. 
As discussed earlier, a firm's governance depends both on the governance of the country in which it is located and on firm-specific governance choices. A number of organizations rate the governance of firms. Unfortunately, the ratings of firms in Eastern Europe are extremely limited. We could only find 14 firms rated. These ratings are from Credit Lyonnais Securities Asia (CSLA).

The CLSA survey was conducted in 2001 and it rates the corporate governance practices of 495 firms from 25 countries (see Gil, 2001). This survey has been used in a number of recent papers (for instance, Chen, Chen, and Wei, 2003; Khanna, Kogan, and Palepu, 2005; Durnev and Kim, 2005; Klapper and Love, 2004; and Krishnamurti, Sevic, and Sevic, 2003). The main criterion for including firms in the CLSA survey is firm size and investor interest. The CLSA corporate governance rating is based on a questionnaire given to financial analysts who responded with "Yes" or "No" answers to 57 questions related to seven categories: management discipline, transparency, independence, accountability, responsibility, fairness, and social responsibility. A composite governance rating is computed by giving an equal weight of 15 percent to the first six categories and a weight of 10 percent to social responsibility. Percentage scores on the composite governance ratings range from 13.9 to 93.5.

Figure 5 shows the average scores for firms in Eastern European countries as well as average scores for the other countries in which firms are rated by CSLA. We find that the average CSLA rating in all Eastern European countries is lower than the average CSLA rating across all countries. Strikingly, in the 2001 CSLA ratings, the highest rating for an Eastern European firm was 60.4 for a Hungarian firm. So, even though the CSLA ratings have a wide range, no Eastern European firm was close to the maximum. Of course, ratings of this sort are imperfect and may exhibit biases. Therefore, they have to be treated with caution.

Berglof and Pajuste (2005) provide evidence on disclosure for Eastern Europe. They construct their own indices of disclosure. One index looks at the information reported on a firm's web site. Another index looks at annual reports. Unfortunately, the indices cannot be benchmarked on other countries, which makes their interpretation difficult. However, a major result of Berglof and Pajuste (2005) is that 
firms in a number of Eastern European countries disclose less than the law requires them to disclose, so that disclosure laws do not appear to be enforced well in some countries.

With the evidence so far that the twin agency problems are significant in Eastern Europe, it is perhaps not surprising that overall firm valuations are low. One way to see that is to compute Tobin's q for the firms for which data is available on Worldscope for 2004. This was done by Doidge, Karolyi, and Stulz (2005b). With Tobin's q, a value below one indicates roughly that the value created by management is negative. Tobin's q averages to 1.06 for Hungary, 0.98 for the Czech Republic, 1.70 for Poland, and 1.20 for Turkey. (Note, however, that some of these markets experienced a very high return in 2005 which improved valuations substantially.) Doidge et al. compute Tobin's q for 9,250 non-U.S. firms. The average $\mathrm{q}$ for these firms is 1.45 .

According to the Bank for International Settlements (BIS), no Polish firms and no Hungarian firms had an outstanding international debt issue with more than one year of maturity since 2001 . While the corporate sector of the Czech Republic and of Turkey had international corporate debt outstanding, the issues took place in 2004 for a total of \$400 million for Turkey and \$200 million for the Czech Republic. From 2002 through 2004, the amount of international equity issues is $\$ 1.3$ billion for the Czech Republic, $\$ 800$ million for Hungary, $\$ 1.7$ billion for Poland, and \$1 billion for Poland. ${ }^{9}$ Only one firm from Turkey and only one firm from Hungary had a listing on a U.S. exchange, while there is strikingly, however, no firm from the Czech Republic or from Poland had an ADR listed on a U.S. exchange.

It follows from the analysis that we would expect weak financial development in Eastern European countries. Figure 6 shows that this is the case. Using data from the IMF, we see that the ratio of stock market capitalization to GDP is strikingly low in Eastern European countries compared even to emerging markets in general. This would still be the case after taking into account the stock market performance of these countries in 2005 . The same is true for bank assets.

The analysis of Section 3 implies that foreign holdings should be low in Eastern Europe. One source of data for foreign holdings is the U.S. Treasury International Capital System (TIC) data. It reports 
holdings of foreign assets by U.S. residents. Figure 7 shows the fraction of stock market capitalization held by U.S. investors in each of the four Eastern European countries and for comparison shows the median fraction of market capitalization held by U.S. investors across all countries as well as across Western European countries. We expect low ownership by U.S. investors given the governance issues discussed so far and this is what we find. U.S. investors hold a smaller fraction of market capitalization in the typical Eastern European country than they do across the world.

The story emerging from the data we have shown is that Eastern European countries have room to improve with governance at the firm level as well as at the country level. The theory discussed in Section 2 predicts that poor governance leads to concentrated ownership, low valuations, and reduced participation by foreign investors. The evidence from Eastern Europe is consistent with this prediction (though recent increases in the stock markets of these countries temper our conclusions with respect to valuations).

\section{The road to better governance.}

In the analysis presented so far, ownership concentration arises because corporate insiders cannot commit not to take advantage of outside shareholders. Corporate insiders would be better off if, at the time they sell securities to the public for the first time, they could commit not to take advantage of outside shareholders. Unfortunately, their ability to make such a commitment depends on the institutions of the country in which the firm is located. In this conclusion, some issues associated with corporate governance reform are discussed.

As first stressed by Bebchuck and Roe (1999), incumbents who have already sold securities find governance reform that makes it harder for them to consume private benefits expensive. The incumbents have paid for their private benefits by selling securities at a lower price. Reform that makes it harder for them to consume these benefits means that they paid for the benefits in full. Insiders will only find reform valuable if it allows them to sell part of their stake, so that they can diversify their holdings, and if it enables them to sell securities at a higher price. 
When firms issue securities, good governance makes it possible to sell these securities at a higher price. To avoid opposition to reform from incumbents who view such reform as expropriation, governance reform should focus on the rights of holders of securities issued after the reform. Further, governance reform should both increase the rights of investors and the incentives of firms to acquire good governance. In particular, firms should be free to raise funds abroad, since this makes it more valuable for firms to have good governance.

${ }^{1}$ Thomas L. Friedman, 2005, The World is Flat, Farrar, Strauss, and Giroux.

${ }^{2}$ For a review of issues concerning capital flows, see Stulz (1999).

${ }^{3}$ Data from the IMF's World Economic Outlook.

${ }^{4}$ See McGuire and Olson (1996).

${ }^{5}$ See, for instance, Bekaert and Harvey (2000), Henry (2000), and Stulz and Wasserfallen (1995).

${ }^{6}$ Dahlquist, Pinkowitz, Stulz, and Williamson (2003)

${ }^{7}$ See Feldstein and Horioka (1980).

${ }^{8}$ See Obstfeld (1994).

${ }^{9}$ All the BIS data are from the BIS Quarterly Review, September 2005. 


\section{References}

Bae, K.-H., R. M. Stulz, and H. Tan (2005), 'Do Local Analysts Know More? A Cross-Country Study of the Performance of Local Analysts and Foreign Analysts', Unpublished working paper, Dice Center, The Ohio State University, Columbus, OH.

Bekaert, G., and C. Harvey (2000), 'Foreign Speculators and Emerging Equity Markets', Journal of Finance, 55, 565-613.

Bebchuck, L. A., and M. J. Roe (1999), 'A Theory of Path Dependence in Corporate Ownership and Governance', Stanford Law Review, 52, 127-170.

Berglof, E., and A. Pajuste (2005), 'What Do Firms Disclose and Why? Enforcing Corporate Governance and Transparency in Central and Eastern Europe', Working Paper, Stockholm School of Economics, Stockholm, Sweden.

Chen, K., Z. Chen, and K. Wei (2003), 'Disclosure, Corporate Governance, and the Cost of Equity Capital: Evidence From Asia's Emerging Markets', Working Paper, Hong Kong University of Science and Technology.

Dahlquist, M., L. Pinkowitz, R. M. Stulz, and R. Williamson (2003), 'Corporate Governance and the Home Bias', Journal of Financial and Quantitative Analysis, 38, 87-110.

Desai, M.A., A. Dyck, and L. Zingales (2005), 'Corporate Governance and Taxation', Unpublished Working Paper, University of Chicago.

Doidge, C., A. Karolyi, and R.M. Stulz (2004), 'Why Are Foreign Firms Listed in the U.S. Worth More?', Journal of Financial Economics, 71, 205-238.

Doidge, C., A. Karolyi, and R.M. Stulz (2005a), 'Why Do Countries Matter So Much For Corporate Governance?', Unpublished Working Paper, Dice Center, The Ohio State University, Columbus, OH.

Doidge, C., A. Karolyi, and R.M. Stulz (2005b), 'The Valuation Premium For Non-U.S. Firms Listed on U.S. Stock Markets, Unpublished.

Durnev, A., and Kim, E.H. (2005), 'To Steal Or Not To Steal: Firm Attributes, Legal Environment, and Valuation', Journal of Finance, 60, 1461-1493.

Dyck, A., and L. Zingales (2004), 'Private Benefits of Control: An International Comparison', Journal of Finance, 59, 537-600.

Faccio, M. (2005), ‘Politically Connected Firms', American Economic Review, forthcoming.

Feldstein, M. and C. Horioka (1980), 'Domestic Saving and International Capital Flows', Economic Journal, 90, 314-329.

Fisman, R. (2001), 'Estimating the Value of Political Connections', American Economic Review, 91, 1095-1102.

Friedman, T. L. (2005), The World is Flat, Farrar, Strauss, and Giroux, New York, N.Y. 
Giannetti, M., and A. Simonov (2005), 'Which Investors Fear Expropriation? Evidence From Portfolio Choices', Journal of Finance, forthcoming.

Gill, A. (2001), 'Corporate Governance in Emerging Markets: Saints and Sinners, Who's got religion?', Credit Lyonnais Securities Asia.

Henry, P.B. (2000), 'Stock Market Liberalization, Economic Reform, and Emerging Market Equity Prices', Journal of Finance, 55, 529-564.

Jin, L., and S. C. Myers (2005), ' $\mathrm{R}^{2}$ Around the World: New Theory and New Tests', Journal of Financial Economics', forthcoming.

John, K., L. Litov, and B. Yeung (2005), 'Corporate Governance and Corporate Risk Taking: Theory and Evidence', Unpublished Working Paper, New York University, New York, NY.

Johnson, S., and T. Mitton (2003), 'Cronyism and Capital Controls: Evidence From Malaysia', Journal of Financial Economics, 67, 351-382.

Kaufmann, D., A. Kraay, and M. Mastruzzi (2005), 'Governance Matters IV: Governance Indicators for 1996-2004', World Bank Policy Research Working Paper 3630, Washington, D.C.

Khanna, T., J. Kogan, and K. Palepu (2005), 'Globalization and Similarities in Corporate Governance: A Cross-Country Analysis', Review of Economics and Statistics, forthcoming.

Klapper, L., and I. Love (2004), 'Corporate Governance, Investor Protection and Performance in Emerging Markets', Journal of Corporate Finance, 10, 703-728.

Klapper, L. F., L. Laeven, and I. Love (2005), 'What Drives Corporate Governance Reform? Firm-Level Evidence From Eastern Europe’, World Bank Policy Research Working Paper 3600, Washington, D.C.

Krishnamurti, C., A. Sevic, and Z. Sevic (2003), 'Legal Environment, Firm-Level Corporate Governance, and Expropriation of Minority Shareholders in Asia', Working Paper, Nanyang Technological University, Singapore.

La Porta, R., F. Lopez-De-Silanes, and A. Shleifer (1999), 'Corporate Ownership Around the World', Journal of Finance, 54, 471-517.

Lucas, R. E. Jr. (1990), 'Why Doesn't Capital Flow From Rich to Poor Countries?', American Economic Review, 80, 92-96.

McGuire, M.C., and M. Olson, Jr. (1996), 'The Economics of Autocracy and Majority Rule: The Invisible Hand and the Use of Force', Journal of Economic Literature, 34, 72-96.

Obstfeld, M. (1994), 'Risk-Taking, Global Diversification, and Growth', American Economic Review, $84,1310-1329$.

Pajuste, A. (2002), 'Corporate Governance and Stock Market Performance in Central and Eastern Europe', Unpublished Working Paper, Stockholm School of Economics, Stockholm, Sweden. 
Pinkowitz, L., R. Williamson, and R.M. Stulz (2005), 'Does the Contribution of Corporate Cash Holdings and Dividends to Firm Value Depend on Governance? A Cross-Country Analysis', Journal of Finance, forthcoming.

Roe, M. (2003), Political Determinants of Corporate Governance, Oxford University Press, Oxford.

Rajan, R. G., and L. Zingales (2003), 'The Great Reversals: The Politics of Financial Development in the Twentieth Century', Journal of Financial Economics, 69, 5-50.

Shleifer, A., and R.W. Vishny (1989), 'Management Entrenchment: The Case of Manager-Specific Investments', Journal of Financial Economics, 25, 123-140.

Stulz, R. M. (1999a), 'International Portfolio Flows and Security Markets', in Martin Feldstein (ed) (1999), International Capital Flows, University Chicago Press, pp. 257-293.

Stulz, R.M. (1999b), 'Globalization, Corporate Finance and the Cost of Capital', Journal of Applied Corporate Finance, 12(3), 8-25.

Stulz, R. M. (2005), ‘The Limits of Financial Globalization', Journal of Finance, 60, 1595-1638.

Stulz, R. M., and W. Wasserfallen (1995), 'Foreign Equity Investment Restrictions, Capital Flight, and Shareholder Wealth Maximization: Theory and Evidence', Review of Financial Studies, 8, 1019-1057. 
Figure 1: Impact of financial globalization on the amount of capital raised in the absence of the twin agency problems.

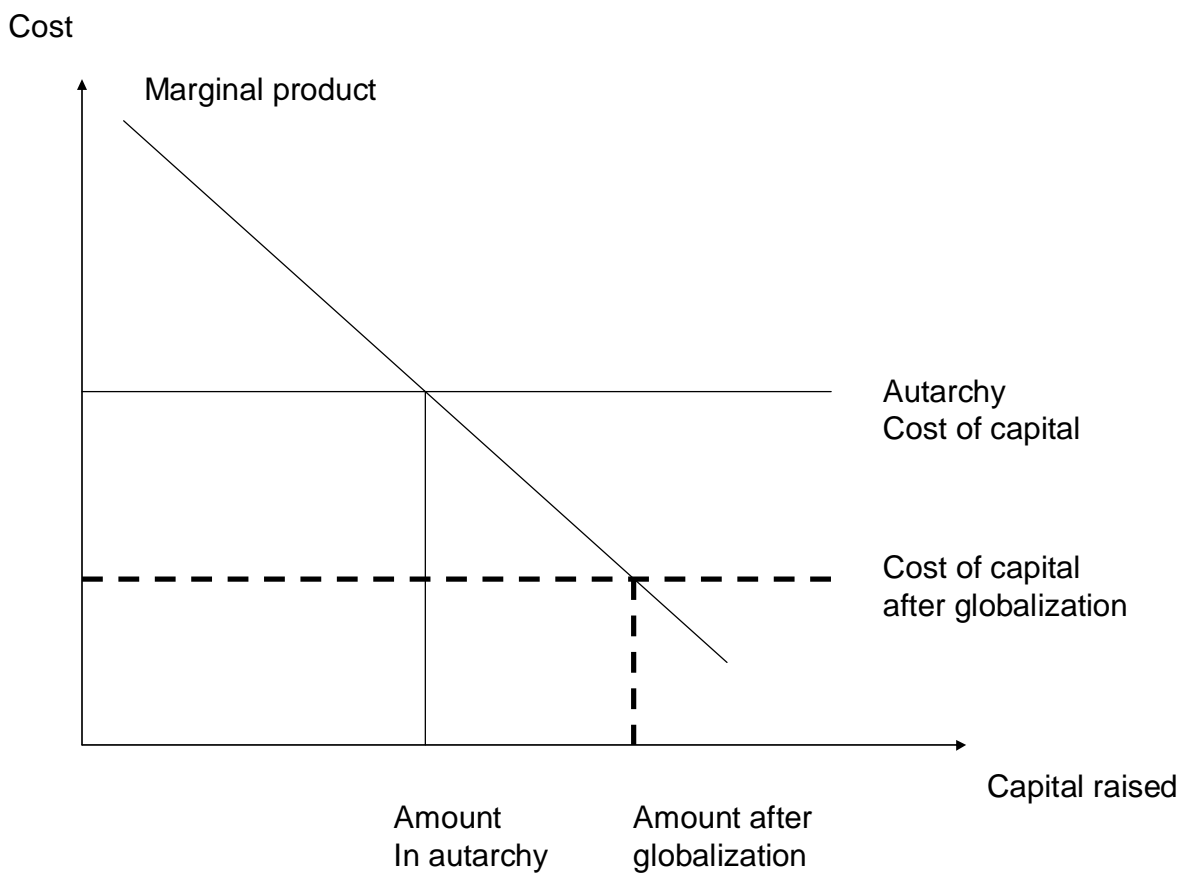

Figure 2: Impact of financial globalization on the amount of capital raised in the presence of the twin agency problems.

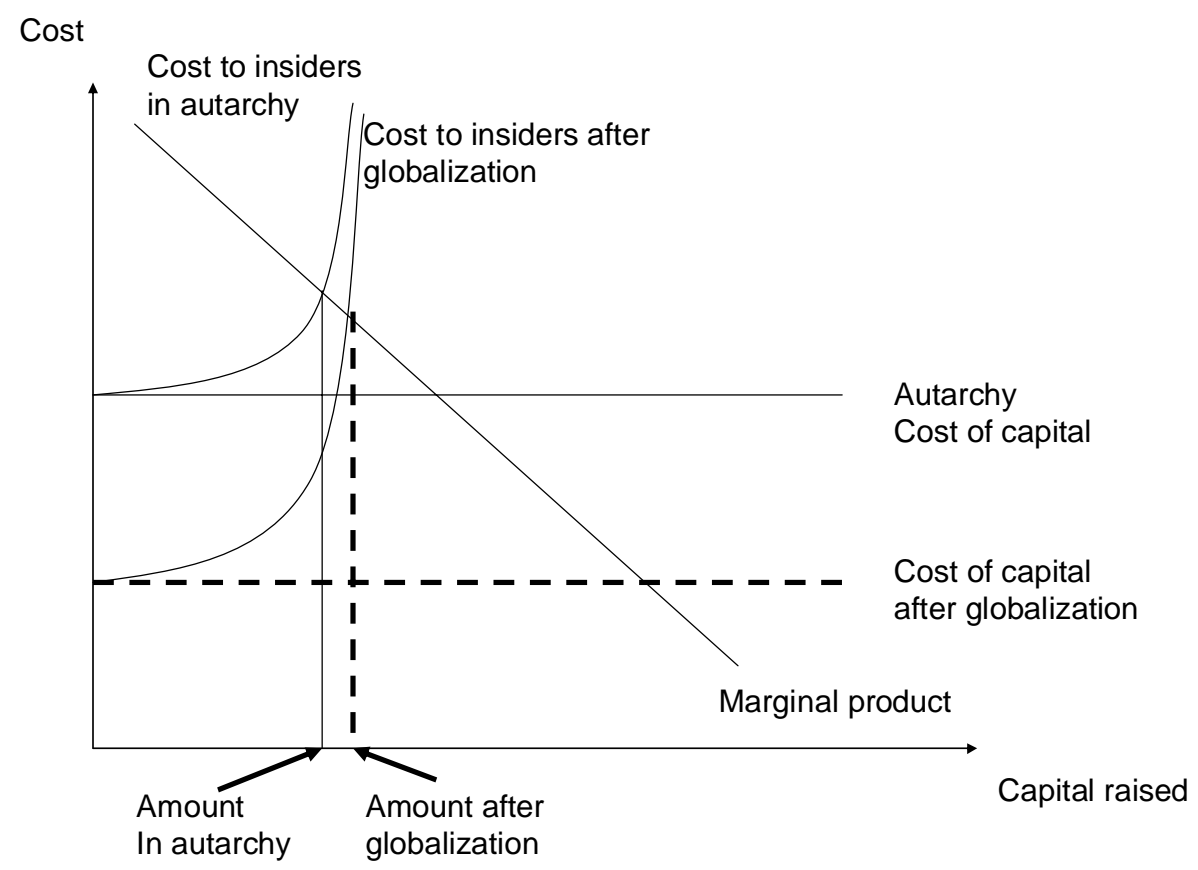


Figure 3. Insider ownership in Eastern European countries over time.

The figure reports the equally-weighted average and the value-weighted average of closely-held shares reported by Worldscope for Eastern European countries in 2002.

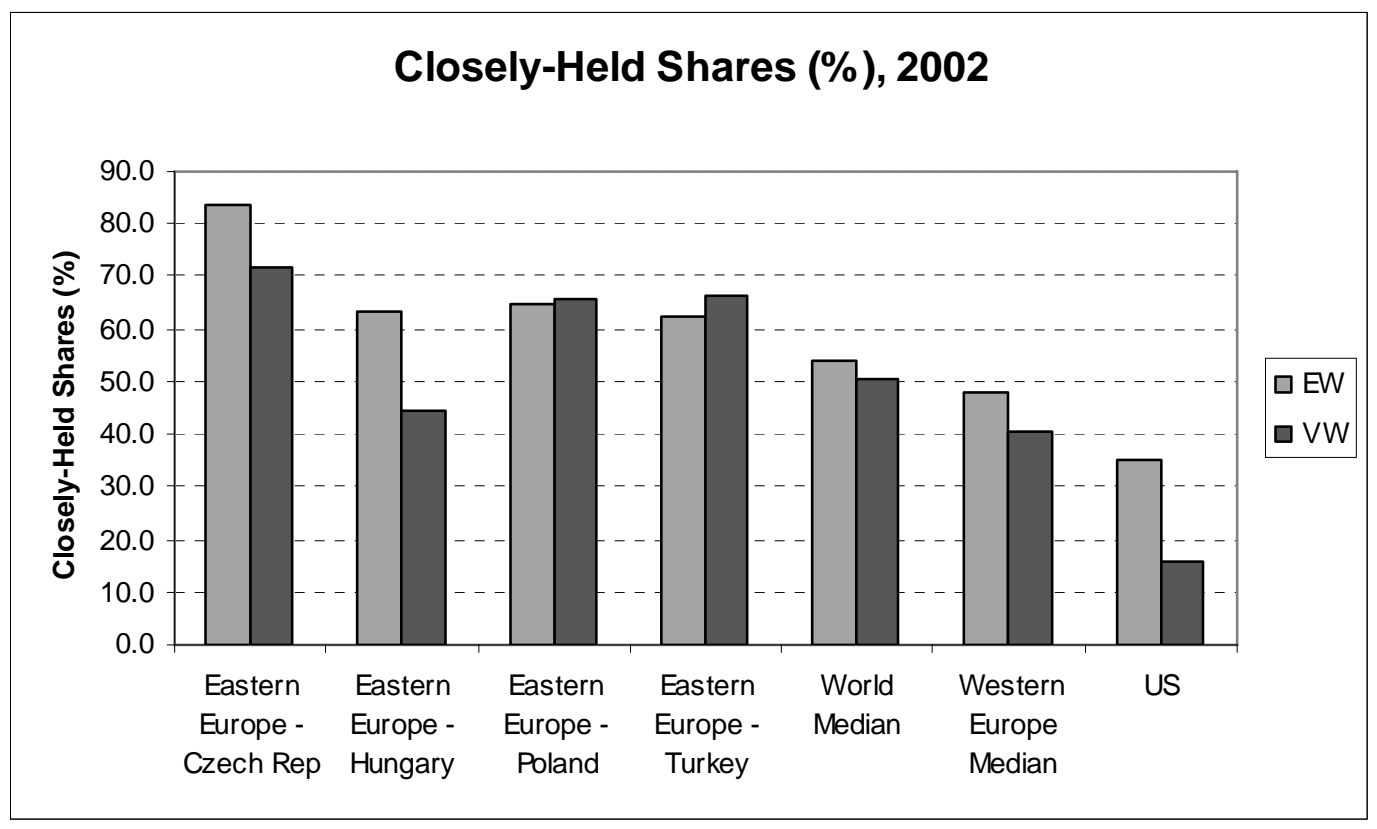

Figure 4. Insider ownership in Eastern European countries over time.

The figure reports the equally-weighted average of block ownership reported by Worldscope for Eastern European countries.

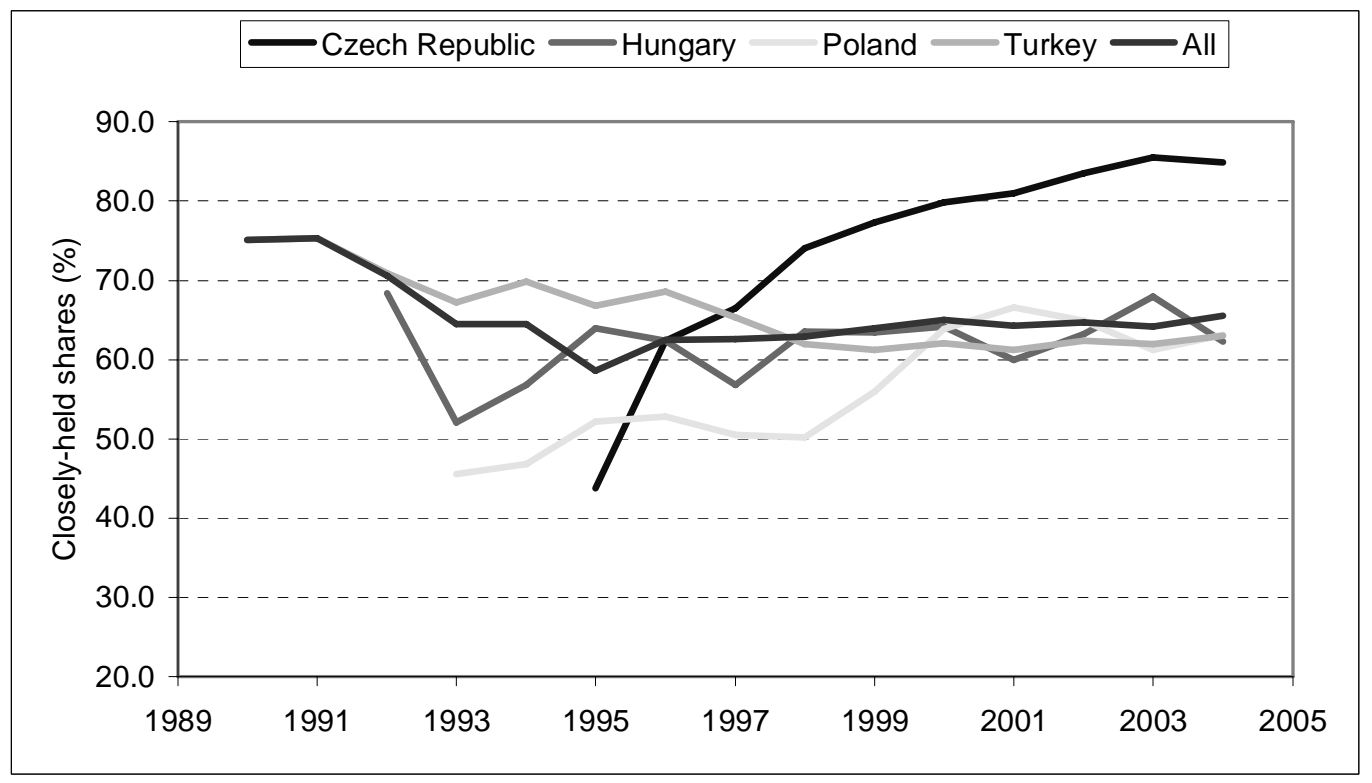


Figure 5. Average CSLA rating per country.

The figure reports the equally-weighted average CSLA rating per country using the 2001 version of the CSLA rating.

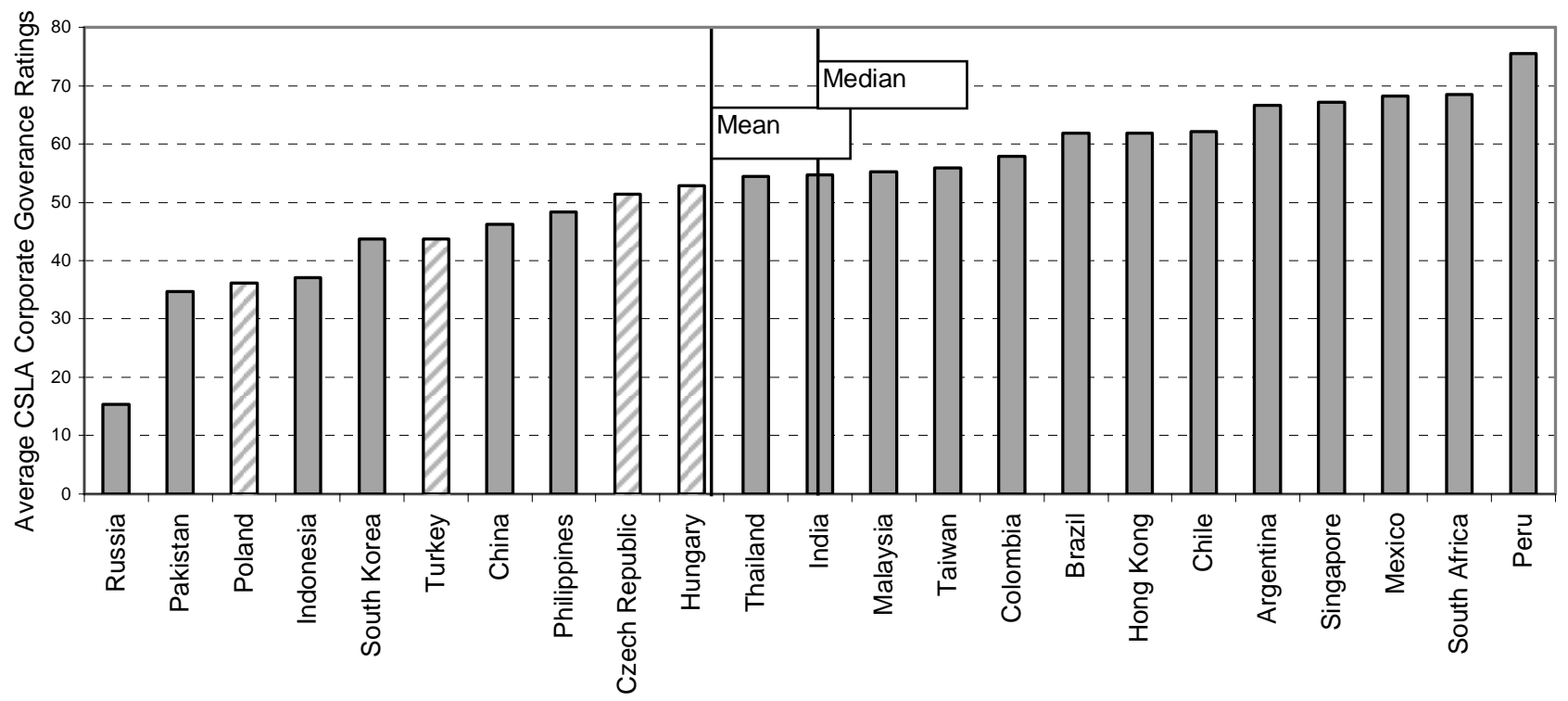


Figure 6. Measures of financial development for 2004.

The data are obtained from the IMF's Financial Stability Report, 2005.

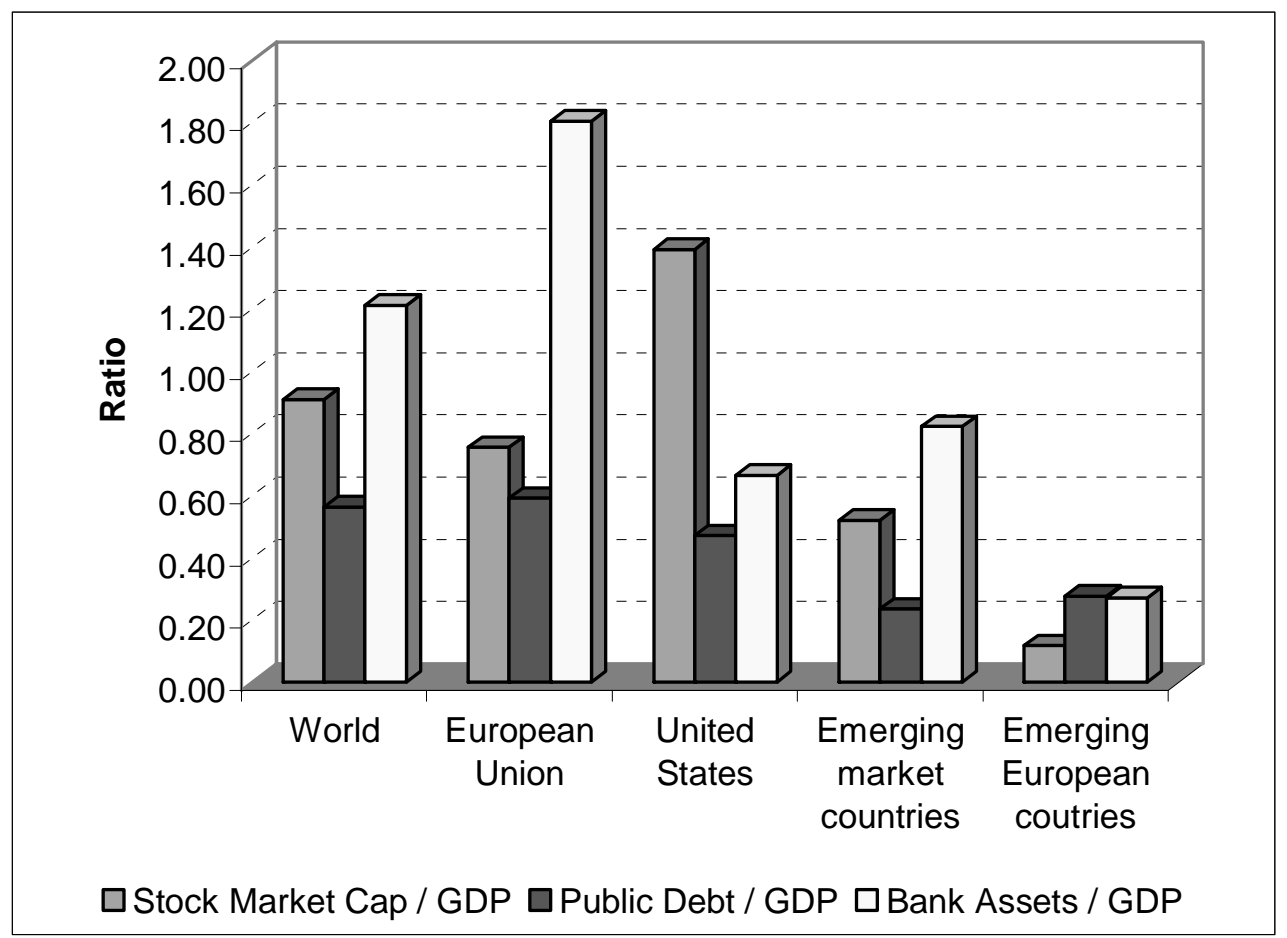


Figure 7. US ownership in Eastern European equity markets.

This figure uses the data reported in the Report on US portfolio holdings of foreign securities of December 31, 2003, from the US Department of the Treasury.

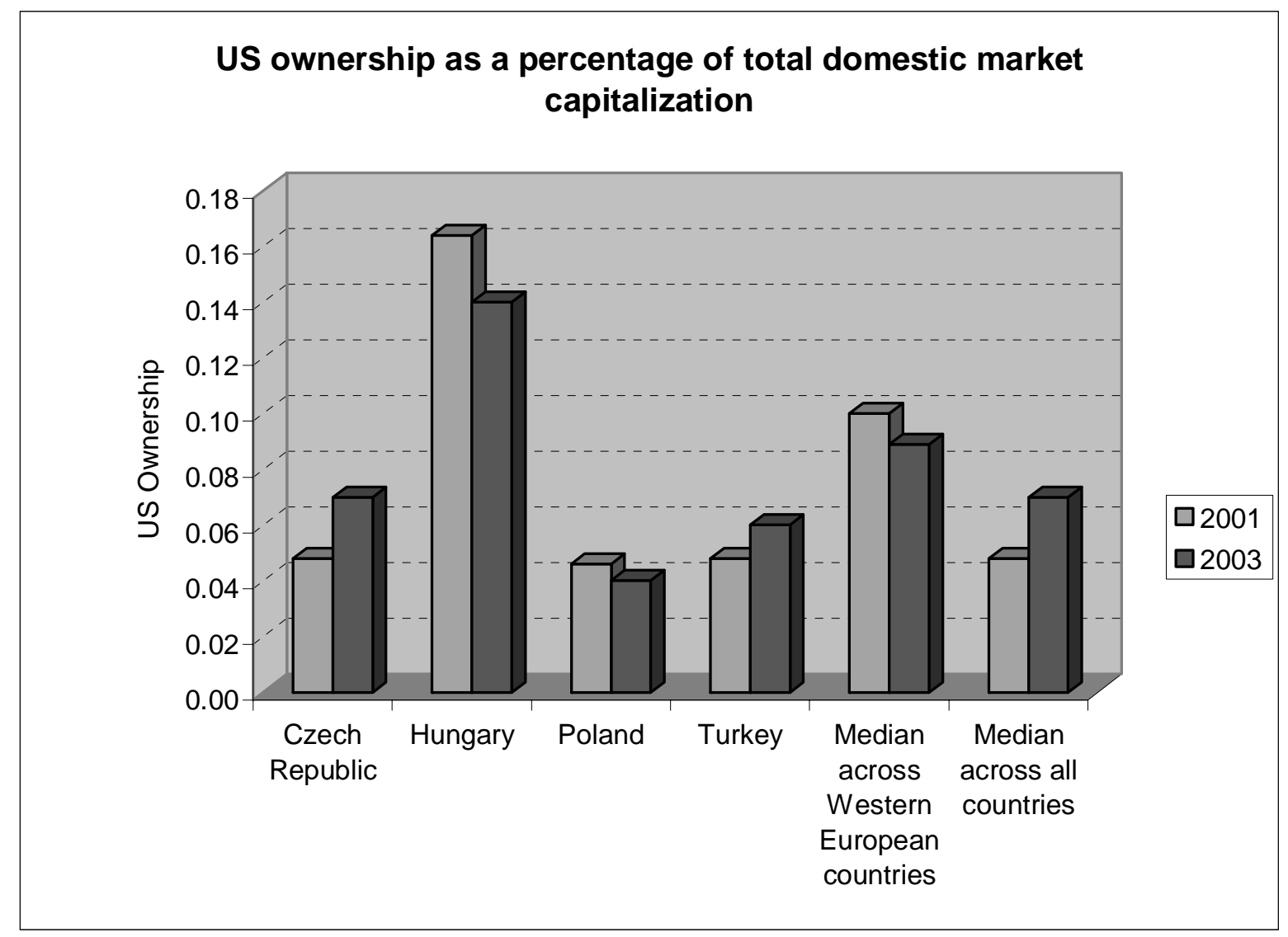


Table 1. Governance indicators for Eastern European countries.

This table reports the governance indicators from Kaufmann, Kraay and Mastruzzi (2005) for Eastern European countries, average cross countries from their income categories and average across Western countries (Europe, the U.S. and Canada). Rule of Law and Control of Corruption are the same as in Kaufmann, Kraay and Mastruzzi (2005). Overall is the average of the six component governance indicators - voice and accountability, political instability and violence, government effectiveness, regulatory quality, rule of law, and control of corruption.

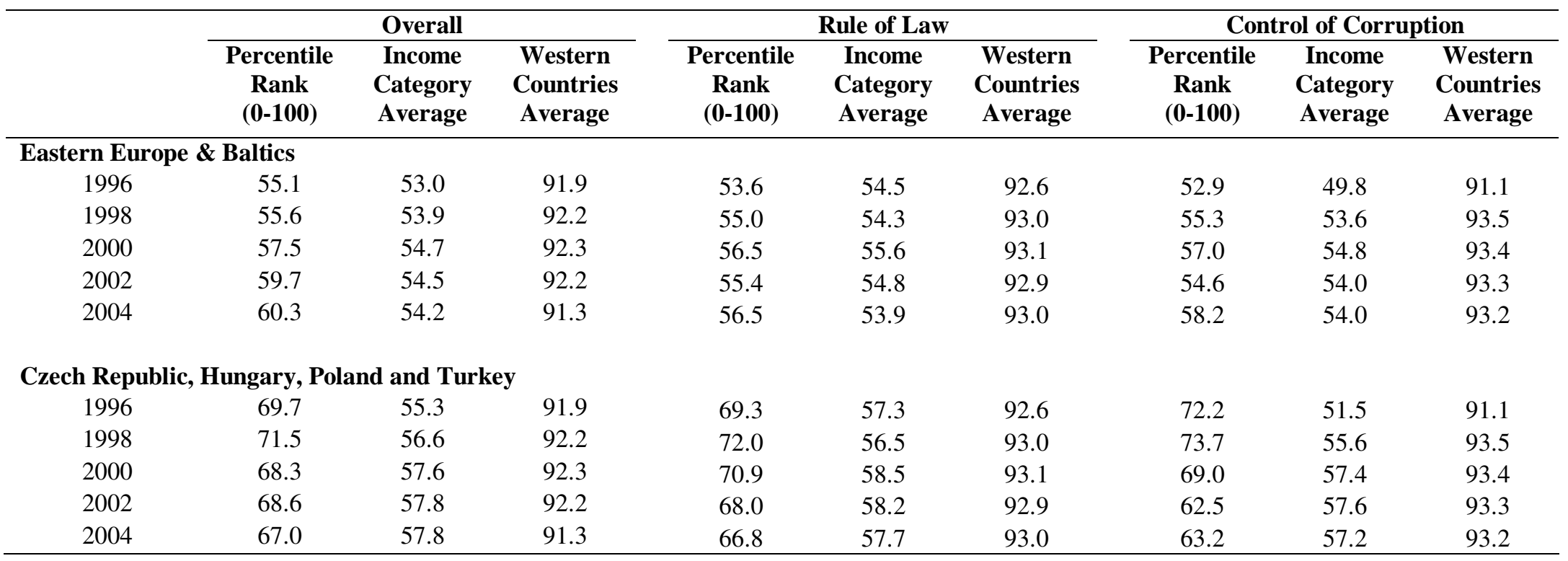

